\title{
PROBLEM OF RESEARCH IN ISLAMIC ECONOMICS
}

\author{
Khairunnisa ${ }^{1}$ \\ Universitas Muhammadiyah Sumatera Utara, Medan, Indonesia \\ khairunnisa@umsu.ac.id
}

\author{
Revita Sari ${ }^{2}$ \\ Universitas Muhammadiyah Sumatera Utara, Medan, Indonesia \\ revitasari@umsu.ac.id
}

\begin{abstract}
Indonesia is currently the country with the largest Muslim population in the world. The total Muslim population of $80 \%$ makes an Islamic-based economy possible to expand widely related to fashion, culinary, tourism, cosmetics, and various topics. Currently, the Indonesian government, practitioners, and academics are working hard to improve the performance of the Islamic finance industry. Understanding that Islamic Economics is only related to Islamic finance is too shallow perception. Many other sectors can be developed, including the hotel business, tourism, culinary, fashion, hotel, other topics. However, research related to the sectors mentioned is very minimal. The phenomenon is happening because most Islamic economic research worldwide discusses topics related to the financial sector. The researchers have been interested in discussing the development of research on Islamic Economics at the University of Muhammadiyah North Sumatra (UMSU) for the last four years. The research is descriptive because the existing data is not processed to accept or reject the hypothesis. The sample selection criteria in this study are all UMSU student thesis related to Islamic economics for the last four years from 2017 - 2020. The results of the study found that out of 499 theses, the majority of students' research was around the theme of Islamic banking, which was 78\%, other themes (including MSMEs, e-commerce, Sharia marts) were $6 \%$, the ZISWAF theme and Halal Industry got the same percentage. Namely, $5-6 \%$, the Islamic Capital Market theme at 3.4\%, the Fashion and Cosmetics theme at 2\%, and the Insurance theme at only $0.8 \%$. considering the current research conditions, it is time for the study program to develop Islamic economic research outside Islamic banking.
\end{abstract}

Keywords: Methodology, Islamic Economic, Education, Social Sciences 


\section{INTRODUCTION}

Islamic economics as a science has become a global phenomenon. Indonesia is currently the country with the largest Muslim population globally, around 231 million people in 2021 (Kusnandar, 2021). The total Muslim population of 86,7\% makes the economic potential with Islamic principles to expand widely related to fashion, culinary, tourism, cosmetics, and other topics. Indonesia is a leading country in using social networks, making it a prime target for marketing and publicity purposes. Based on Hootsuite and We Are Social (2019) data, 150 million internet users in Indonesia spend 8 hours 36 minutes every day. Meanwhile, $76 \%$ of internet users in Indonesia make purchases through e-Commerce.

Currently, the Indonesian government, practitioners, and academics are working hard to improve the performance of the Islamic finance industry. However, in contrast to the penetration of social networks, currently, the penetration of Islamic finance can only reach $9.68 \%$ in July 2020. Understanding that Islamic Economics is only related to financing Sharia is too shallow perception. Many other sectors can be developed, including the hotel business, tourism, culinary, fashion, and so forth. The phenomenon is happening because most Islamic economic research around the world discusses topics related to the financial sector. At the level of the Scopus Q1 indexed journal researched by Rusydiana (2020), it shows that Islamic economic research is still dominated by the theme of Islamic banking (42\%), Islamic capital market (31\%), Islamic accounting (9\%), Islamic business and marketing (7\%), Islamic monetary (4\%) and other economic problems such as takaful, microfinance, halal industry, waqf and hajj economy (7\%). Rusydiana, Marlina, and Rani (2019) explained in their research entitled, "Malmquist Productivity Index on Islamic Economics and Finance Research." Whereas in the period 2006 to 2019 that research on the theme of Islamic Economics that implemented MPI was $73 \%$ for Islamic banks, $12 \%$ for Sharia Insurance, $8 \%$ Zakat, 4\% related to Sharia micro-financial issues, and the rest were issues related to the halal industry, waqf, and Sharia REITs.

North Sumatra is one of the largest provinces in Indonesia. Currently, many universities are opening Islamic Economics study programs. At least, seven campuses open study programs related to Islamic Economics. However, if final year student research is accessed through the university repository, it is found that the majority of research is 
carried out in the financial sector, such as banks, insurance, the ZISWAF Institute, and BMT. In addition, more than two-fifth students can't integrate the perspective of Islamic economics into their research. In the future, it is hoped that the Islamic economy will continue to grow, but if the research culture is not improved, it will slow down the development of the Islamic economy in the long term.

UMSU is a private university in North Sumatra that has A-accreditation. UMSU has two study programs related to Islamic Economics, namely Islamic Banking and Sharia Business Management, under the Faculty of Islamic Religion. Both study programs have existed since 2008. However, from many studies that have been carried out, only less than a fifth of articles are publishes in reputable journals and are used as references in other journal articles. Based on this background, the authors are interested in discussing the development of research on Islamic Economics at UMSU for the last four years.

The research is critical do for several reasons. The first, as a basis for further research related to the Islamic economic research area. The second, it can be a policy reference for study programs to direct students to conduct research that has not been further elaborated.

\section{REVIEW OF LITERATURE}

\section{Islamic Economics}

Manan (1980) states that Islamic economics is a social science that studies the economic problems of society inspired by Islamic values. Chapra (2016) defines Islamic economics as knowledge to realize human welfare through allocating and distributing limited resources concerning Islamic laws. Meanwhile, Siddiqi (2010) states that Islamic economics is the response of Muslim scholars to the current economic challenges.

\section{Five Biggest Challenges in Islamic Economics Education}

Sayyid (2008), in his article, indicates five factors that are a challenge for the world of education in Islamic Economics, including: a) Paradigm: Lecturers and researchers introduce the subject and explain the main issues with individual perceptions. The lack of an agreed explanation regarding the rationalization of Islamic Economics institutions; b) Sharia and its Teachings: The approach to Sharia issues cannot keep up with the speed of the times; c) Curriculum: The Islamic economics research culture is mostly just looking for 
a degree, not knowledge. Most research is not reflected in resolving issues related to Islamic finance; d) Teaching Materials: There is no specific standard regarding teaching materials. Most of the teaching materials are the result of dissertations which are used as textbooks which make it difficult for undergraduate students to understand; e) Teaching Staff: Most universities use temporary teaching staff who do not have a comprehensive understanding of Sharia, Banking, and Finance issues. It is due to the limitations of academics who understand this and cause student dissatisfaction.

\section{Relevant Study}

The motivation for developing an Islamic economic system is to achieve a just distribution for humanity. However, based on a study conducted by Abduh (2013), most of the issues currently being discussed in the academic world are technical aspects related to Islamic financial institutions, and little discussion is related to other aspects that discuss a just economic and financial system. Six major issues are widely discussed related to Islamic Economics, namely Islamic Banking, other Islamic financial institutions, Zakah-Waqf and poverty alleviation, Islamic monetary system, and Fiqh Muamalah Maliyah (Ainorrofiqie, 2021).

Adibuddin, Setiawan, and Sutopo (2019) made a study entitled, "The Recent Development of Islamic Economic Studies in Indonesia." The study took 14 years of data from 2004 to 2017. There was a significant increase in articles published in accredited national journals. The majority of research focuses on the banking sector (52.7\%), Capital Market (25.5\%), ZISWAF (4.3\%), and Insurance (3.3\%). The method used is the analytical method $(58.2 \%)$ followed by the literature review method (30.4\%) and using a survey (11.4\%). In his research, Khan mentions several factors that make it challenging to produce quality research related to Islamic finance, namely: a) Lack of transparency and disclosure related to Sharia banking incidents; b) Propaganda and misinformation spread by Islamic bank practitioners; c) Copyright and lack of access to electronic publications and knowledge monopoly.

In addition, the results of interviews with several academics concluded that there were; (1) weak synergy between economists and Fiqh scientists creates a dichotomy where the two do not understand each other; (2) lack of knowledge related to research methods and data processing; (3) research topics are not solution-oriented (4) researchers do not 
follow news and issues related to Islamic economics; (5) the same research topic and repeated.

Within the scope of UMSU, various studies to increase student participation in learning and methods for the allocation of supervisors have been carried out. The Faculty of Computer Science will implement the allocation of thesis supervisors using the Topsis method. This method uses several criteria, including the lecturers' final education, competence, available courses, and the quota of students taught to guide students to work on a quality thesis (2021). Meanwhile, Hayati and Sitompul (2017) found that the peer teaching-learning model is an alternative model used in the classroom. The method can improve students' affective abilities, especially in accounting courses.

Other research conducted is related to the level of financial literacy of students in the Faculty of Economics and Business (Nurmala et al., 2021 and Sarim M, Lubis, N.A.B \& Jufrizen, 2021). In other research related to the level of financial literacy, it was found that the majority of lecturers at the Faculty of Economics and Business were at the lowest level of $83.5 \%$. Where lecturers aged 23 to 35 years have a fairly low literacy level (Gunawan, A, Pulungan, D.R, Koto, M, 2019).

\section{RESEARCH METHOD}

The study uses data from a student thesis from UMSU with the theme related to Islamic Economics during the 2017 - 2020 period accessed through the UMSU repository. The methodology used is a quantitative method with descriptive statistics. The research is descriptive because the existing data is not processed to accept or reject the hypothesis. The analysis results are in the form of descriptions related to the observed phenomena and do not have to be in the form of numbers (Subana \& Sudrajat, 2005). McClave \& Sincich (2009) stated that descriptive statistics use numerical methods and graphs to see patterns in a data set to conclude the information obtained in the form of a data set and present the information in an easy-to-understand form. Ms. Excel processed this research to summarize data and display it in tables or graphic presentations.

The research uses the judgment sampling method, selecting a sample from a population with certain considerations based on expert opinion or scientific considerations (Juliandi \& Irfan, 2014). The sample selection criteria were all UMSU students' thesis 
related to Islamic economics for the last four years from 2017 - 2020. In addition, the researchers will also distribute questionnaires to the student population whose research in that year related to obstacles in doing the final project.

\section{RESULTS AND DISCUSSION}

Based on the observations made on student thesis accessed through the UMSU repository, it was found that 499 theses from 2017 to 2020 were discussing the theme of Islamic Economics at the Faculty of Islamic Religion, namely; Islamic Banking Study Program and Sharia Business Management Study Program. As for the Faculty of Economics study program, there are two study programs, where students write thesis related to Islamic Economics, namely; Accounting Study Program and Management Study Program.

In table 1 it can be seen that the Islamic Banking Study Program produced the most thesis with the theme of Islamic Economics. It was due to the two study programs, namely; Sharia Banking and Sharia Business Management requires students to write a final project with the theme of Sharia Economics. As for the Faculty of Economics, several Islamic Economics courses are elective courses, so the students are not required to write a thesis with Islamic Economics.

Table 1

Total Thesis on Islamic Economics from 2017 - 2020

\begin{tabular}{|l|c|c|c|c|}
\hline \multirow{2}{*}{ Department } & 2017 & 2018 & 2019 & 2020 \\
\cline { 2 - 5 } & $\begin{array}{c}\text { Number of } \\
\text { Articles }\end{array}$ & $\begin{array}{c}\text { Number of } \\
\text { Articles }\end{array}$ & $\begin{array}{c}\text { Number of } \\
\text { Articles }\end{array}$ & $\begin{array}{c}\text { Number of } \\
\text { Articles }\end{array}$ \\
\hline Islamic Banking & 74 & 35 & 135 & 81 \\
\hline $\begin{array}{l}\text { Sharia Business } \\
\text { Management }\end{array}$ & 9 & 28 & 38 & 27 \\
\hline Accounting & 11 & 23 & 12 & 2 \\
\hline Management & 6 & 3 & 9 & $\mathbf{1 1 6}$ \\
\hline Total & $\mathbf{1 0 0}$ & $\mathbf{8 9}$ & $\mathbf{1 9 4}$ & 6 \\
\hline
\end{tabular}

Resource : Repository UMSU 2017 - 2020

In table 2, it can be seen that the majority of students' research is around the theme of Islamic banking, which is $78 \%$, other themes (including MSMEs, e-commerce, Sharia marts) are 6\%, the ZISWAF and Halal Industry themes get the same percentage of 5-6\%, 
the Islamic Capital Market theme at 3.4\%, the Fashion and Cosmetics theme at $2 \%$ and the Insurance theme at only $0.8 \%$.

Table 2

Total Thesis on Islamic Economics from 2017 - 2020

\begin{tabular}{|l|c|c|c|c|c|}
\hline \multirow{2}{*}{$\begin{array}{c}\text { Research } \\
\text { Topics }\end{array}$} & $\begin{array}{c}\text { Number of } \\
\text { Articles }\end{array}$ & $\begin{array}{c}\text { Number of } \\
\text { Articles }\end{array}$ & $\begin{array}{c}\text { Number of } \\
\text { Articles }\end{array}$ & $\begin{array}{c}\text { Number of } \\
\text { Articles }\end{array}$ & Total \\
\cline { 2 - 5 } $\begin{array}{l}\text { Banking and } \\
\text { Financial }\end{array}$ & 81 & 61 & 158 & 83 & $\mathbf{3 8 3}$ \\
\hline Insurance & 0 & 2018 & 1 & 1 & $\mathbf{4}$ \\
\hline $\begin{array}{l}\text { Shariah } \\
\text { Capital } \\
\text { Market }\end{array}$ & 3 & 5 & 5 & 4 & $\mathbf{1 7}$ \\
\hline $\begin{array}{l}\text { ZISWAF } \\
\text { ZISW }\end{array}$ & 4 & 6 & 7 & 7 & $\mathbf{2 8}$ \\
\hline $\begin{array}{l}\text { Halal Goods } \\
\text { And Services }\end{array}$ & 9 & 6 & 7 & 5 & $\mathbf{2 7}$ \\
\hline
\end{tabular}

Resource: Repository UMSU 2017-2020

The university is the birthplace of intellectuals and a symbol of the progress of knowledge of a nation. Research conducted by students should contribute new insights amid widespread public enthusiasm regarding Islamic Economics. However, it can be seen from the table presented that the students tend to write research with the theme of Islamic banking, although many other themes can be developed. UMSU has a Sharia Investment Gallery, an extension of the Indonesia Stock Exchange, located within the Faculty of Islamic Religion. Since the Covid-19 pandemic, Capital Market investors have continued to grow.

However, research related to the Islamic Capital Market only obtained a percentage of $3.4 \%$. In addition, insurance growth, which reached $5 \%$ in 2020 , is exciting to study, but the insurance theme does not even reach $1 \%$ as a theme of interest to students. Abduh's (2013) research entitled, "Prioritizing Issues in Islamic Economics and Finance," found six areas of Islamic economic research that are most widely studied, namely Islamic banks and other financial institutions Zakah-Waqaf and poverty alleviation, the Islamic monetary system, and Fiqh. Mullah. However, with the AHP method, it was decided that the ZakahWaf research area and poverty alleviation were the most important themes to be researched. Currently, at UMSU, the portion of students' research related to Zakah, Infaq, Alms, and 
Waqf is still 5-6\%. Poverty is still the most prominent economic problem today. Research related to Islamic Economics should focus on solving this problem. However, most students are not interested in researching themes outside of Islamic banking. The phenomenon should concern the study programs in order that the student research outputs can solve economic problems.

\section{CONCLUSION}

The research provides information related to the conditions of Islamic economic research in four study programs at the Faculty of Islamic Religion for the period 2017 2020. It helps to map the current state of student research to assist study programs develop Islamic economic research in the future. Currently, research related to ZISWAF should be encouraged to do more in the future.

\section{REFERENCES}

Abduh, Muhammad. (2013). Prioritizing Issues in Islamic Economics and Finance. Middle-East Journal of Scientific Research. 15(11), 1594-1598. DOI: 10.5829/idosi.mejsr.2013.15.11.11658.

Adibuddin, AF., Setiawan, D., Sutopo, Bambang. (2019) The Recent Development of Islamic Economic Studies in Indonesia, Syirkah: Journal of Economics and Business, 4(1), 133-174, DOI : 10.22515/shirkah.v4i1.263.

Ainorrofiqie, A., Khasanah, U., \& Djalaluddin, A. (2021). Lalabet Financial Analysis: Study of Islamic Economics at Micro Level. Indonesian Interdisciplinary Journal of Sharia Economics (IIJSE), 4(1), 233-244. https://doi.org/10.31538/iijse.v4i1.1506.

Ardianto, Prisma.(2020, September 25). Pangsa Pasar Keuangan Syariah Bisa Digenjot 25\%. Investor Daily Indonesia. Accessed from https://investor.id/.

Chapra, M. U. (2016). Islam and The Economic Challenges. UK, The Islamic Foundation.

Gunawan, A., Pulungan, D. R., \& Koto, M. (2019). Tingkat Literasi Keuangan Dosen Fakultas Ekonomi dan Bisnis Universitas Muhammadiyah Sumatera Utara. Seminar Bisnis Magister Manajemen (SAMBIS) (pp. 1-9). Surakarta: Universitas Muhammadiyah Surakarta.

Hayati, I., \& Sitompul, D. N. (2017). Pengaruh Model Pembelajaran Peer Teaching Terhadap Peningkatan Aspek Afektif Mahasiswa Pada Mata Kuliah Akuntansi Keuangan Program Studi Perbankan Syariah Universitas Muhammadiyah Sumatera Utara. Jurnal Masharif Al-Syariah, 2(2), 1-19. DOI: http://dx.doi.org/10.30651/jms.v2i2.1133

J.T., Sincich, T. (2009). Statistics (Seventh Edition). New Jersey (US), Pearson Education. 
Juliandi, Azuar., \& Irfan. (2014). Metodologi Penelitian Kuantitatif untuk Ilmu - Ilmu Bisnis. Medan (ID), Citapustaka Media Perintis.

Khan, T. (2017). Remedy for Unproductive Researches and Disintegrated Information in Islamic Finance: "Riba Information Queries Digital Portal". 5(2), 106 -117. DOI: 10.14421/grieb.2017.052-04.

Kusnandar, V. B. (2021, November 11). Databooks. (D. J. Bayu, Editor) Retrieved January 10, 2022, from Katadata: https://databoks.katadata.co.id/datapublish/2021/11/03/persentase-populasi-muslimindonesia-posisi-35-dunia.

Manan, MA. (1980). Islamic Economics, Theory and Practice. India (IN), Idarah Adabiyah. McClave.

Nurmala, F., Arya, M., Nurbaiti, N., \& Putri, L. P. (2021). Analisis Tingkat Literasi Keuangan Mahasiswa di Tengah Pandemi (Studi Kasus Pada Mahasiswa FEB UMSU). Maneggio : Jurnal Ilmiah Magister Manajemen, 4(2), 307-314. DOI: http://dx.doi.org/10.30596\%2Fmaneggio.v4i2.7856.

Ramadhani, F., Al-Khowarizmi, \& Sari, I. P. (2021). Implementasi Metode Topsis dalam Menangani Masalah Pengalokasian Dosen Pembimbing Skripsi dilingkungan Fakultas Ilmu Komputer dan Teknologi Informasi Universitas Muhammadiyah Sumatera Utara. InfoTekjar: Jurnal Nasional Informatika Dan Teknologi Jaringan, 6(1), 104-110. DOI: https://doi.org/10.30743/infotekjar.v6i1.4363.

Rusydiana, A. S. (2020, April 16). Literature Studies of Islamic Economics and Finance Research in Scopus Indexed Journal Q1. Al-Muzara'ah, 8(1), 39-56. doi:10.29244/jam.8.1.39-56.

., Marliana, L., \& Rani, L.N. (2019). Malmquist Productivity Index on Islamic Economics and Finance Research. Syirkah: Journal of Economics and Business, 4(1), 99132. DOI: 10.22515/shirkah.v4i1.261.

Sari, M., Lubis, N. B., \& Jufrizen. (2021). The Effect Of Financial Literature and Self Control On Consumption Behaviour (Study on Students of The Faculty of Economics and Business Universitas Muhammadiyah Sumatera Utara). IJEBAS, l(2), 135-144. DOI: https://doi.org/10.54443/ijebas.v1i2.40.

Siddiqi, M.N. (2010). Role of the State in the Economy: An Islamic Perspective. UK, The Islamic Foundation.

Subana dan Sudrajat. (2005). Dasar-dasar Penelitian Ilmiah. Bandung (ID), Pustaka Setia.

Tahir, Sayyid. (2009). Islamic Finance-Undergraduate Education. Islamic Economic Studies 16(1\&2). https://www.researchgate.net/publication/323173536_ISLAMIC_FINANCEUNDE RGRADUATE_EDUCATION.

Wong, Emily. (2019, Maret 18). How Indonesians embrace the digital world. The Jakarta Post. Accessed from https://www.thejakartapost.com. 